\title{
Correction to: A theoretical derivation of response to selection with and without controlled mating in honeybees
}

Manuel Du* (1), Richard Bernstein, Andreas Hoppe and Kaspar Bienefeld

\section{Correction to: Genet Sel Evol (2021) 53:17}

https://doi.org/10.1186/s12711-021-00606-5

Following publication of the original article [1], the authors reported an error in Table 1 . The lines are not correctly aligned.

The correct Table 1 is given below:

The original article can be found online at https://doi.org/10.1186/s1271

$1-021-00606-5$.

*Correspondence: manuel.du@hu-berlin.de

Institute for Bee Research Hohen Neuendorf, Friedrich-Engels-Str. 32

16540 Hohen Neuendorf, Germany

(c) The Author(s) 2021. This article is licensed under a Creative Commons Attribution 4.0 International License, which permits use, sharing, adaptation, distribution and reproduction in any medium or format, as long as you give appropriate credit to the original author(s) and the source, provide a link to the Creative Commons licence, and indicate if changes were made. The images or other third party material in this article are included in the article's Creative Commons licence, unless indicated otherwise in a credit line to the material. If material is not included in the article's Creative Commons licence and your intended use is not permitted by statutory regulation or exceeds the permitted use, you will need to obtain permission directly from the copyright holder. To view a copy of this licence, visit http://creativeco mmons.org/licenses/by/4.0/. The Creative Commons Public Domain Dedication waiver (http://creativecommons.org/publicdomain/ zero/1.0/) applies to the data made available in this article, unless otherwise stated in a credit line to the data. 
Table 1 Variable definitions

\begin{tabular}{ll}
\hline Variable & Definition \\
\hline$t$ & $\begin{array}{c}\text { Subscript referring to the year. If variables are used without this subscript it is assumed that they are } \\
\text { constant for all years } \\
\text { Average true breeding value of breeding/passive colonies of year } t\end{array}$ \\
$B_{t} / P_{t}$ & $=B_{t}-B_{t-1}\left(\right.$ resp. $\left.=P_{t}-P_{t-1}\right)$ Annual genetic gain among the breeding/passive colonies \\
$\Delta B_{t} / \Delta P_{t}$ & $=B_{t}-P_{t}$ Genetic lag between the breeding population and the passive population \\
$D_{t}$ & Time lag, time it takes for the passive population to reach the genetic level of the breeding population \\
$T$ & Probability that a sire drone in an uncontrolled mating comes from a breeding colony \\
$p_{t,} p$ & Proportion of passive queens with a dam queen from the breeding population \\
$q_{t}, q$ & Genetic selection differential of colonies selected for breeding queen production \\
$S_{1, t}, S_{1}$ & Genetic selection differential of colonies selected for DPQ production \\
$S_{2, t}, S_{2}$ & Number of breeding/passive colonies per year \\
$N_{b} / N_{p}$ & Maternal/direct heritability \\
$h_{m}^{2} / h_{d}^{2}$ & Correlation between maternal and direct effects \\
$r_{m d}$ &
\end{tabular}

Published online: 24 February 2021

\section{Reference}

1. Du M, Bernstein R, Hoppe A, Bienefeld K. A theoretical derivation of response to selection with and without controlled mating in honeybees. Genet Sel Evol. 2021;53:17. https://doi.org/10.1186/s12711-021-00606-5.

\section{Publisher's Note}

Springer Nature remains neutral with regard to jurisdictional claims in published maps and institutional affiliations. 